\title{
ELEMENTY EDUKACJI IB NA LEKCJACH JĘZYKA POLSKIEGO W KLASACH WIELOKULTUROWYCH
}

\begin{abstract}
Slowa kluczowe: edukacja IB, International Baccalaureate, edukacja polonistyczna, uczeń z doświadczeniem migracyjnym, nauczanie przez działanie, nauczanie przez dociekanie

Streszczenie. Celem niniejszego artykułu jest przedstawienie problematyki nauczania języka polskiego w klasie szkolnej, w której co najmniej jeden z uczniów posługuje się językiem polskim jako drugim. Badacze zajmujący się omawianą kwestią sugerują konieczność opracowania materiałów do nauczania języka polskiego dla wszystkich etapów edukacyjnych. Niniejszy artykuł podejmuje to zagadnienie, a także stanowi wstęp do szerszych badań mających na celu opracowanie warsztatu pracy nauczyciela polonisty nauczającego w klasie, w której znajdują się uczniowie $\mathrm{z}$ doświadczeniem migracyjnym. Podstawowe pytanie, jakie przyświeca podjętym tu rozważaniom, odnosi się do efektywności nauczania: jak uczyć i jakie działania edukacyjne podejmować, by zaangażować w proces nauczania zarówno uczniów, dla których język polski jest językiem pierwszym, jak i uczniów, dla których jest to język drugi? W tekście przedstawiono metody nauczania stosowane $w$ edukacji międzynarodowej oraz propozycje ich adaptacji na lekcjach języka polskiego w klasach wielokulturowych.
\end{abstract}

\section{WPROWADZENIE}

Liczba uczniów z doświadczeniem migracyjnym w polskich szkołach stale rośnie. Dane na ten temat podawane są przez dyrektorów wszystkich placówek edukacyjnych: przedszkoli i szkół, łącznie z policealnymi oraz rejestrowane w Systemie Informacji Oświatowej. Według informacji udostępnionych przez Ministerstwo Edukacji Narodowej w latach szkolnych 2010/2011-2013/2014 liczba uczniów cudzoziemskich w szkołach i placówkach oświatowych wyniosła średnio 7,5 tys. dzieci (Fihel 2014). Według danych MEN w roku szkolnym 2018/2019 liczba dzieci z doświadczeniem migracyjnym w wieku 7-18 lat, które korzystają

*nataliakuzma@kul.lublin.pl, Katolicki Uniwersytet Lubelski Jana Pawła II, Wydział Nauk Humanistycznych, Instytut Językoznawstwa, Katedra Języka Polskiego, Al. Racławickie 14, 20-950 Lublin. 
z nauki w szkołach publicznych, wzrosła do 44 tys. cudzoziemców. W okresie ośmiu lat liczba dzieci cudzoziemskich i uczniów-reemigrantów wzrosła prawie sześciokrotnie, co oznacza, że każdego roku wiele dzieci obcego pochodzenia rozpoczyna naukę w Polsce i musi radzić sobie z nowym systemem, odmiennymi wymaganiami, często również z nauką w języku obcym. Uczniowie, dla których język polski jest drugim lub kolejnym, muszą odnaleźć się w całkowicie nowej rzeczywistości społecznej, kulturowej, językowej oraz szkolnej. Bardzo często komunikacja z dziećmi obcego pochodzenia jest utrudniona - nie potrafią one porozumiewać się w obcym języku, jednak podejmują naukę wielu przedmiotów w ten sam sposób, w który uczą się dzieci mieszkające w Polsce od urodzenia.

Niniejszy artykuł zawiera rozważania będące wprowadzeniem do szerszych badań koncentrujących się na perspektywie nauczyciela w klasie wielokulturowej, tj. takiej, w której co najmniej jeden z uczniów doświadczył migracji ${ }^{1}$. Doświadczenie pracy w publicznej placówce edukacyjnej oraz w międzynarodowej autoryzowanej szkole International Baccalaureate (IB) pozwala mi na porównanie systemów edukacyjnych polskiego i międzynarodowego oraz stworzenia na tej podstawie propozycji działań dydaktycznych oraz materiałów edukacyjnych, które mogą wspomóc nauczycieli polonistów w pracy z dziećmi w klasach mieszanych. Celem tego opracowania jest prezentacja zarysu koncepcji opracowania planowanych narzędzi i metod oraz przykładowych rozwiązań dotyczących wybranych zagadnień kształcenia polonistycznego w grupach różnokulturowych.

\section{NAUCZANIE JEZYKA POLSKIEGO A MIGRACJE - KWESTIE TERMINOLOGICZNE I ROZWIĄZANIA LEGISLACYJNE}

W polskich szkołach, poza uczniami obcego pochodzenia, odnaleźć się muszą również uczniowie $\mathrm{z}$ doświadczeniem migracyjnym $\mathrm{w}$ innym rozumieniu - są to uczniowie-reemigranci powracający do ojczyzny rodziców. Zarówno ich obecność w polskiej klasie, jak i obecność dzieci uchodźców w systemie edukacyjnym, wymusiły rewizję dotychczasowych podejść do nauczania języka polskiego jako obcego, zwłaszcza w odniesieniu do kształcenia dzieci i młodzieży.

W. Miodunka $(2010,2013)$ za francuskim słownikiem Dictionnaire de linguistique definiuje język ojczysty jako sposób komunikacji używany w kraju, w którym lokutor w sposób naturalny poznawał otoczenie i świat, z którym się identyfikuje. Dla dziecka wychowywanego w Polsce, uczącego się w polskim przedszkolu i szkole, takim językiem będzie język polski. Jeśli chodzi o polszczyznę dzieci polonijnych, to wspomniany badacz nazywa ją językiem drugim, nie jest

${ }^{1}$ Badania te zostaną opublikowane w przygotowywanej pod kierunkiem dr hab. Magdaleny Smoleń-Wawrzusiszyn rozprawie doktorskiej, której celem jest stworzenie warsztatu pracy nauczyciela polonisty pracującego w klasie międzykulturowej. 
ona bowiem językiem obcym ani ojczystym. W 2012 roku E. Lipińska i A. Seretny zrewidowały ujęcie Miodunki i w odniesieniu do języka typowego dla diaspory polonijnej zastosowały termin język odziedziczony² (Lipińska, Seretny 2012, s. 26). Natomiast jako język drugi autorki rozumieją „nie-rodzimy język uczącego się, posiadający status prawny (urzędowy) w miejscu uczenia się" (Lipińska, Seretny 2012, s. 26). Nowe spostrzeżenia dotyczące powyższych ustaleń zaprezentowała A. Szybura, która zdefiniowała na gruncie glottodydaktyki polonistycznej termin język edukacji szkolnej: ,[jest to] język uczniów imigranckich i reemigranckich w Polsce, którego opanowanie bezpośrednio wiąże się z procesem edukacji" (Szybura 2016, s. 100). Badaczka zwraca uwagę na trzy role tego języka. Po pierwsze, jest on przedmiotem nauczania, a celem, ku któremu zmierza proces dydaktyczny, jest rozwój kompetencji komunikacyjnej (umożliwiającej m.in. funkcjonowanie w szkole i zwykłe codzienne porozumiewanie się). Pełni również funkcję medium pozwalającego na zdobywanie wiedzy przedmiotowej, między innymi za pomocą słownictwa specjalistycznego. Ostatecznie jest również narzędziem samorealizacji: rozwój indywidualny i społeczny odbywa się dzięki językowi, co oznacza, że brak znajomości języka opóźnia możliwość pełnego rozwoju albo wręcz go uniemożliwia (tamże).

Jeśli chodzi o rozstrzygnięcia legislacyjne związane z interesującą mnie problematyką, to opierają się one na ustawach i rozporządzeniach Ministerstwa Edukacji Narodowej dotyczących uczniów cudzoziemskich i reemigrantów.

O najnowszych działaniach legislacyjnych dotyczących omawianej kwestii przeczytać można w Rozporządzeniu Ministra Edukacji Narodowej z dn. 9 września 2016 roku w sprawie ksztatcenia osób niebędacych obywatelami polskimi oraz osób będacych obywatelami polskimi, które pobieraty nauke w szkołach funkcjonujacych $w$ systemach oświaty innych państw (por. Majcher-Legawiec 2017). Nowym rozwiązaniem opracowanym przez MEN jest tworzenie oddziałów przygotowawczych, które Majcher-Legawiec określa jako separacyjny model edukacji w szkole polskiej (Majcher-Legawiec 2017, s. 247). Jak podaje MEN: „Aby umożliwić szybkie i efektywne włączenie uczniów przybywających z zagranicy do polskiego systemu oświaty, od 1 września 2017 r. umożliwiono tworzenie w szkołach oddziałów przygotowawczych. Do takiego oddziału może zostać zakwalifikowany uczeń, jeśli nie zna języka polskiego lub posługuje się nim w stopniu podstawowym, ma trudności adaptacyjne związane z różnicami kulturowymi lub ze zmianą środowiska edukacyjnego spowodowane na przykład wcześniejszym kształceniem za granicą lub trudności spowodowane przez sytuacje kryzysowe lub traumatyczne, wynikające z konfliktów zbrojnych, klęsk żywiołowych lub innych kryzysów humanitarnych" (MEN 2019).

${ }^{2}$ Tematykę języka odziedziczonego autorki rozwinęły w publikacji Język oddziedziczony - polszczyzna pokoleń polonijnych (Lipińska, Seretny 2016) oraz w artykule Język odziedziczony a dwujęzyczność - o konieczności badań komparatywnych (Lipińska, Seretny 2019). 
Dodatkowo uczniowie cudzoziemscy mają prawo do skorzystania z pomocy udzielanej przez osobę władającą językiem kraju pochodzenia - asystenta migranta. Osobę taką dyrektor szkoły może zatrudnić na okres nie dłuższy niż 12 miesięcy. Cudzoziemcom oraz obywatelom polskim przybywającym z zagranicy umożliwiono również korzystanie $\mathrm{z}$ dodatkowych zajęć wyrównawczych $\mathrm{z}$ danego przedmiotu na okres 12 miesięcy. Ich wymiar nie może w sumie przekroczyć pięciu godzin tygodniowo. Placówki dyplomatyczne i konsulaty oraz inne placówki kulturalne i oświatowe mogą również zorganizować naukę języka i kultury kraju pochodzenia uczniów cudzoziemskich uczących się w Polsce. Dla uczniów cudzoziemskich przygotowano również procedury dostosowania czasu pracy podczas egzaminów kończących naukę na danym etapie edukacyjnym (Majcher-Legawiec 2017, s. 250).

Przedstawiony stan prawny świadczy o tym, że w pierwszym roku pobytu w polskiej szkole uczniowie przybywający z zagranicy mają zapewnioną pomocą dydaktyczną dostosowaną do ich możliwości językowych. Mimo tego wielu badaczy zwraca uwagę na brak rozwiązań metodycznych i systemowych, które pozwoliłyby na efektywne nauczanie języka polskiego dzieci i młodzieży z doświadczeniem migracyjnym. P. Gębal (2018) wskazuje między innymi na konieczność opracowania materiałów do nauczania języka polskiego jako drugiego dla wszystkich etapów edukacji szkolnej. Gębal (2018), Szybura (2016) oraz Majcher-Legawiec (2017) zauważają potrzebę zatrudniania w polskich szkołach nauczycieli języka polskiego jako obcego i drugiego. Co więcej, sugerują, że zawód ten powinien zostać wpisany na listę zawodów regulowanych. Obecnie funkcję nauczyciela języka polskiego jako drugiego $\mathrm{w}$ ramach wspomnianych powyżej zajęć dodatkowych pełnią nauczyciele poloniści, którzy nie zawsze posiadają przygotowanie z zakresu glottodydaktyki polonistycznej.

Rozwiązania legislacyjne MEN mogą być wykorzystywane w pracy z dziećmi i młodzieżą przez pierwszy rok pobytu w polskiej szkole. Należy jednak zastanowić się, co dzieje się po upływie dwunastu miesięcy. Jak interesujący nas uczniowie funkcjonują w kolejnych latach nauki w polskim systemie edukacyjnym? Kto i w jaki sposób monitoruje ich sytuację? I, co najważniejsze, czy rok intensywnej pracy dodatkowej, często pozalekcyjnej, wystarczy, by zaadaptować się do nowego systemu, nowych wymagań wychowawczych, dydaktycznych i kulturowych?

Przeprowadzone przeze mnie obserwacje z perspektywy nauczyciela, trwające przez dziesięć miesięcy roku szkolnego 2018/2019 w publicznej placówce edukacyjnej, pokazały, że rok pracy z dziećmi z doświadczeniem migracyjnym nie wystarczy, by zapewnić im poczucie przynależności do obcej jeszcze grupy rówieśniczej. Większość pracy nad aklimatyzacją kulturową i dydaktyczną w kolejnych latach edukacji dzieci z zagranicy spoczywa na barkach nauczycieli, którzy nie są przygotowani do realizacji takiego zadania ${ }^{3}$.

\footnotetext{
${ }^{3}$ Kwestię tę porusza szerzej W. Hajduk-Gawron (2019).
} 


\section{WYBRANE MATERIALY WSPIERAJACE NAUCZYCIELI W PRACY W KLASACH MIESZANYCH}

Jedną ze znaczących publikacji dotyczących perspektywy ucznia z doświadczeniem migracyjnym lub ucznia cudzoziemskiego w polskiej szkole jest pakiet edukacyjny Ku wielokulturowej szkole w Polsce opracowany w 2010 r. przez zespół autorów (Bernacka-Langier i in. 2010). W pracy tej został przedstawiony program nauczania języka polskiego jako drugiego dla I, II i III etapu edukacji. Publikacja została podzielona na cztery części. Pierwsza część koncentruje się wokół ogólnych założeń programu nauczania języka polskiego jako drugiego, część drugą poświęcono szczegółowym programom nauczania dla poszczególnych etapów edukacyjnych. Kolejna część omawia procedury przyjęcia ucznia cudzoziemskiego do szkoły, a ostatnia część czwarta zawiera diagnozę umiejętności uczniów oraz praktyczne wskazówki dla nauczycieli języka polskiego jako drugiego, podzielone na poszczególne sprawności językowe. Co ciekawe, w rozdziale trzecim autorzy zwracają uwagę na konieczność uczenia języka drugiego w sposób zadaniowy. Ten postulat jest również zawarty w Europejskim systemie opisu kształcenia językowego (ESOKJ 2003).

Od 2015 roku na stronie internetowej Ośrodka Rozwoju Edukacji umieszczane są sukcesywnie materiały do pracy z uczniami z doświadczeniem migracji. Podzielono je na poszczególne kategorie dotyczące edukacyjnych wyzwań migracyjnych, diagnozy, edukacji międzykulturowej, edukacji antydyskryminacyjnej, literatury związanej z obszarem wielokulturowości i wielojęzyczności, uczniów romskich i współpracy z Gruzją. Materiały te zostały opracowane przez Fundację im. Mikołaja Reja w ramach projektu „W polskiej szkole”. Wspieranie uczniów cudzoziemskich oraz szkót prowadzacych oddziały przygotowawcze (materiały i szkolenia). Autorki poradnika ,,W polskiej szkole”. Materiaty do pracy z uczniami z doświadczeniem migracji. Przewodnik, M. Pamuła-Behrens oraz M. Szymańska, przedstawiły metodę JES-PL, polegającą na wspieraniu „budowania i rozwijania umiejętności językowych, a także komunikacyjnych u uczniów $\mathrm{z}$ doświadczeniem migracji (UDM) $\mathrm{w}$ rodzinie, przede wszystkim $\mathrm{w}$ zakresie języka edukacji szkolnej (JES)" (Pamuła-Behrens, Szymańska 2017, s. 7). Badaczki wskazują na różnice między językiem codziennym i językiem edukacji szkolnej, którym posługują się nauczyciele w trakcie lekcji. Nie ulega wątpliwości, że język drugi jako JES jest dużo trudniejszą i wymagającą większej sprawności językowej odmianą dyskursu. Pamuła-Behrens i Szymańska zwracają uwagę na rolę nauczyciela $\mathrm{w}$ procesie edukacyjnym $\mathrm{w}$ grupie międzykulturowej. Powinien on być biegły w znajomości procesów akwizycji i uczenia się języka obcego i drugiego, znać glottodydaktyczne metody nauczania. W publikacji ukazały się również przykłady ćwiczeń rozwijających sprawności językowe i wskazówki dotyczące pracy 
nauczyciela w klasie międzykulturowej. Omówiony przewodnik stanowi bardzo przydatną bazę dla nauczycieli uczących obcokrajowców w ramach lekcji indywidualnych i dodatkowych, jednak nie obejmuje zagadnienia włączania uczniów $\mathrm{z}$ doświadczeniem migracyjnym $\mathrm{w}$ strategie edukacyjne w klasie mieszanej.

Wśród polskich pomocy dydaktycznych dotyczących nauczania dzieci z doświadczeniem migracyjnym brakuje nadal materiałów angażujących do pracy całą klasę, w której pojawiają się uczniowie z doświadczeniem migracyjnym i stanowią oni zdecydowaną mniejszość. W dalszej części artykułu proponuję strategię nauczania, polegającą na włączaniu podstawowych założeń nauczania międzynarodowego według wytycznych organizacji IB. Zaprezentowane spostrzeżenia ukazane zostały z perspektywy nauczyciela jako lidera zespołu klasowego. W tym rozumieniu pedagog kieruje procesem edukacji, wyznacza jego ramy, stawia przed uczniami problem, którego rozwiązanie powinien wypracować uczeń lub grupa uczniów przy pomocy nauczyciela i dzięki jego wskazówkom.

\section{MIECDZYNARODOWY SYSTEM NAUCZANIA I JEGO APLIKACJA W EDUKACJI POLONISTYCZNEJ DZIECI W KLASACH ZRÓŻNICOWANYCH KULTUROWO I JĘZYKOWO}

\subsection{EDUKACJA IB - KONCEPCJA I GŁÓWNE ZAŁOŻENIA}

Fundację edukacyjną International Baccalaureate założono w 1968 roku w Genewie. Od tego czasu powstały trzy programy edukacyjne, które kształcą dzieci i młodzież w wieku od 3 do 19 lat: Primary Years Programme, Middle Years Programme oraz Diploma Programme. Szkoły IB mają na celu wykształcenie ludzi ciekawych świata, wrażliwych na problemy lokalne i globalne, rozumiejących inne kultury, religie i społeczeństwa, dociekliwych i podejmujących wyzwania. Międzynarodowy system nauczania opiera się na postulatach, metodach i podejściu edukacyjnym reformatorów - Johna Deweya, Alexandera Sutherlanda Neilla, Jeana Piageta i Jerome'a Brunera - którzy stali się kluczowymi i wpływowymi pedagogami edukacji IB. Nauczanie w programach IB odbywa się przede wszystkim poprzez badanie i dociekanie (inquiry-based learning), a dzieci i młodzież uczą się odpowiedzialności za sam proces uczenia się. Fundacja IB w ten sposób mówi o swojej misji: „International Baccalaureate ${ }^{\circledR}$ (IB) to coś więcej niż programy edukacyjne i certyfikaty. W naszym sercu motywuje nas misja tworzenia lepszego świata poprzez edukację"4.

\footnotetext{
${ }^{4}$ [tłumaczenie własne] „The International Baccalaureate ${ }^{\circledR}$ (IB) is more than its educational programmes and certificates. At our heart we are motivated by a mission to create a better world through education." (https://www.ibo.org [29.05.2020]).
} 
U podstaw koncepcji Johna Deweya leży pragmatyczne podejście do nauczania. Pedagog rekomendował odejście od autorytarnego nauczania, a korzystanie z modelu szkoły stawiającej dziecko w centrum działań edukacyjnych i wychowawczych. Swoją filozofię nowej, zreformowanej szkoły oparł na zasadzie „uczenie się przez działanie”. Wiedza teoretyczna była przekazywana dodatkowo, często „przy okazji” praktycznych eksperymentów i doświadczeń (Dewey 1972).

Według A.S. Neilla najważniejszą kwestią edukacji jest wychowywanie dzieci w szczęściu. Uważał, że jego osiągnięcie jest możliwe w szkole, w której uczniom nie ogranicza się ani wolności w zakresie podejmowania decyzji, ani samodzielności w zdobywaniu wiedzy i uczeniu się - twierdził, że szansą na zrównoważony rozwój jest nauka na własnych błędach, poprzez obserwacje konsekwencji działań i czynów. Według niego uczniowie, którzy podejmują edukację $\mathrm{w}$ atmosferze moralizatorstwa i strachu, nie osiągają wyników adekwatnych do możliwości intelektualnych, które posiadają (Neill 1991).

$\mathrm{Na}$ temat znaczącej roli aktywności uczącego się pisali również J. Piaget (1966), L. Wygotski (1971) i J.S. Bruner (1960, 1987), którzy reprezentują nurt konstruktywizmu w teorii uczenia się. Według nich uczeń wchodzi w interakcje $z$ otoczeniem, przyswaja wiedzę, kulturę i światopogląd poprzez relacje z innymi oraz z samym sobą. Proces poznawania zachodzi głównie dzięki wymianie interpersonalnej, którą rozumie się jako wymianę doświadczeń w interakcji ucznia i opiekuna (Piaget 1966). Takie podejście znacznie wpływa na aktywność ucznia, który bierze odpowiedzialność za proces nauczania, dąży do zrozumienia problemu, bada i analizuje przedmioty oraz ludzi. Dla konstruktywistów rola nauczyciela sprowadza się do bycia pośrednikiem pomiędzy stopniami zaawansowania. Wygotski nazywał ten proces „budowaniem rusztowania”, które najsprawniej konstruowane jest $\mathrm{w}$ tak zwanej „strefie najbliższego rozwoju”. Pedagog powinien przedstawiać problem, który dziecko może rozwiązać samodzielne na podstawie poznanych już wcześniej zagadnień (Wygotski 1971). Spostrzeżenia Brunera również dotyczą wpływu środowiska na proces nauczania. Uważał, że proces edukacyjny powinien pomóc uczniom wykształcić narzędzia kulturowe, za pomocą których będą oni w stanie rozumieć zjawiska zachodzące w świecie. Był zwolennikiem uczenia się przez działanie, odkrywanie i doświadczanie (Bruner 1987).

Powyżej przedstawione koncepcje edukacyjne były podstawą stworzenia międzynarodowego programu nauczania International Baccalaureate, programu, który zapamiętywanie i uczenie się na pamięć zastąpił krytyczną analizą, nauczanie na pamięć reguł i definicji zmienił na nauczanie tego, co ciekawi uczniów i rozwija ich zainteresowania. Zamknięte, hermetyczne przedmioty zastąpione zostały projektami międzyprzedmiotowymi i transdyscyplinarnością. Testy inteligencji zmieniono na ranking umiejętności, a sprawdziany i kartkówki zastąpiono 
ocenianiem spełnienia kolejnych kryteriów. Jednak przede wszystkim zmieniono punkt centralny edukacji. W systemie tradycyjnym edukacja stawiająca $\mathrm{W}$ centrum nauczyciela stała się w progresywnym, międzynarodowym systemie nauczania edukacją stawiającą w swoim centrum ucznia wraz z jego potrzebami naukowymi, społecznymi, kulturowymi, wychowawczymi.

Profil ucznia IB opiera się na dziesięciu cechach, które w trakcie edukacji uczniowie powinni rozwijać. Dzieci i młodzież starają się być:

1. Dociekliwymi odkrywcami - potrafią z entuzjazmem uczyć się samodzielnie i we współpracy z innymi.

2. Wnikliwi, dobrze poinformowani - rozwijają i wykorzystują rozumienie pojęć, zgłębiając wiedzę w wielu dziedzinach. Angażują się w działania o znaczeniu lokalnym i globalnym.

3. Myślicielami - uczą się krytycznego i twórczego myślenia w celu analizy sytuacji i podjęcia odpowiedzialnych działań w obliczu złożonych problemów.

4. Komunikatywni - wyrażają siebie pewnie i twórczo w więcej niż jednym języku i na wiele sposobów.

5. Prawymi ludźmi z zasadami - biorą odpowiedzialność za własne działania i ich konsekwencje.

6. Otwartymi ludźmi wolnymi od uprzedzeń - posiadają silne poczucie sprawiedliwości oraz poszanowanie godności i praw ludzi na całym świecie.

7. Wrażliwi, dbający o środowisko - okazują empatię i szacunek, mają potrzebę niesienia pomocy, aby pozytywnie wpłynąć na życie innych i na cały świat.

8. Chętnie podejmującymi wyzwania - pracują zarówno samodzielnie, jak i wspólnie, aby odkrywać nowe pomysły i innowacyjne strategie. Są zaradni i odporni w obliczu wyzwań i zmian.

9. Zrównoważeni - wiedzą, że dla osiągnięcia dobrego samopoczucia i szczęścia niezbędne jest zachowanie równowagi pomiędzy rozwojem intelektualnym, fizycznym i emocjonalnym.

10. Refleksyjni, świadomi swoich możliwości - starają się zrozumieć swoje mocne i słabe strony, aby wspierać proces uczenia się i własny rozwój ${ }^{5}$.

${ }^{5}$ Zachowana oryginalna kolejność cech. Więcej na ten temat można przeczytać na stronie internetowej organizacji IB, dostępnej po adresem: https://www.ibo.org [29.05.2020]. 


\subsection{INSPIRACJE EDUKACJI IB DO PRACY Z KLASA WIELOKULTUROWA}

Konieczność zmiany w strategiach metodycznych nauczania języka polskiego jako drugiego, odziedziczonego lub języka edukacji szkolnej zauważona została również na gruncie glottopedagogiki ${ }^{6}$ polonistycznej. Na wartość wybranych cech uczniów IB, które zostały przytoczone powyżej zwracają uwagę również glottodydaktycy polonistyczni oraz pedagodzy, którzy widzą potrzebę wykształcenia w uczniach klas mieszanych postawy otwartości, ciekawości świata, chęci poznania innych kultur, języków i zwyczajów. P. Gębal w publikacji Podstawy dydaktyki języka polskiego jako drugiego. Podejście integracyjno-inkluzyjne widzi potrzebę adaptacji w glottopedagogice również pojęć i treści z zakresu nauczania międzykulturowego, dydaktyki wielojęzyczności, edukacji włączającej, inkluzji pedagogicznej oraz edukacji pozytywnej (Gębal 2018). Większość rozważań badacza zgodna jest z misją nauczania IB. Gębal zwraca także uwagę na walory nauki języka metodą nastawioną na działanie ucznia (Gębal 2010). Opinię tę podziela I. Janowska, która sugeruje, że każde zadanie „powinno być działaniem spójnym, zorganizowanym, ukierunkowanym na odkrywanie i przekazywanie znaczeń, posiadać związek z rzeczywistością pozaszkolną i uruchamiać proces uczenia się" (Janowska 2011, s. 175).

Podejście zadaniowe rekomendują również redaktorzy wspomnianej już publikacji Ku wielokulturowej szkole w Polsce, powołując się na J. Willis (1996), która wyróżniła trzy rodzaje zadań odpowiadające trzem etapom lekcji: Pre-task (zadanie wstępne), Task cycle (zadanie właściwe) oraz Language focus (praca nad językiem). Jak czytamy w poradniku, „Pre-task to faza przygotowawcza do tematu zasadniczego. Nauczyciel wskazuje na przydatne słownictwo i struktury gramatyczne oraz pomaga uczniom zrozumieć polecenie. $W$ tej fazie lekcji uczniowie mogą też zapoznać się z przykładami wykonania danego zadania. Na etapie Task cycle uczniowie wykonują zadanie w parach lub grupach, a nauczyciel monitoruje pracę, nie włączając się aktywnie. Uczniowie planują rozwiązania problemu, jakie mogą przedstawić klasie, zastanawiają się nad formą prezentacji, a na koniec przedstawiają $\mathrm{w}$ formie ustnej lub pisemnej raport $\mathrm{z}$ wykonania zadania. Language focus jest ostatnią fazą lekcji, w której wyjaśniane są wątpliwości uczniów dotyczące materiałów wykorzystanych w poprzednich częściach lekcji. Nauczyciel może zaproponować ćwiczenia językowe adekwatne do wykonanego zadania" (Bernacka-Langier i in. 2010, s. 28).

${ }^{6}$ Termin 'glottopedagogika interkulturowa' wprowadził do rozważań nad językiem W. Pfeiffer w 2004 roku, zauważając, że glottodydaktyka jest często poszerzana o istotny element pedagogiczny dotyczący kształcenia pozytywnej postawy wobec inności kulturowej, językowej i mentalnej (Pfeiffer 2004). 
Zaproponowane przez polskich autorów rozwiązania są kierowane do uczniów, którzy uczą się języka polskiego jako drugiego. Współcześnie ważnym zadaniem jest także opracowanie bazy materiałów, które mógłby wykorzystać nauczyciel polonista uczący grupę różnokulturową.

Działania, które zostały opisane poniżej, zostały przetestowane w pracy z uczniami w klasach mieszanych w latach: 2018/2019 oraz 2019/2020 w dwóch placówkach edukacyjnych mieszczących się na terenie Lublina. Jedna z placówek należy do autoryzowanych szkół IB, druga jest placówką publiczną. W obu z nich, obok uczniów polskich, naukę pobierają uczniowie z doświadczeniem migracyjnym. Praca w dwóch różnych placówkach, wykorzystujących odmienne systemy nauczania, ukazała wady i zalety każdego z nich oraz pozwoliła na obserwację i analizę metod, które przynoszą zadowalające efekty nauczania w klasach mieszanych. Warto pokreślić, że metody te można stosować od początku pobytu w szkole ucznia z doświadczeniem migracyjnym, jednak muszą być one wsparte zajęciami dodatkowymi z języka polskiego jako drugiego.

Edukatorzy IB rekomendują sięganie do metod, które skupiają się na działaniu uczniów, a nie nauczyciela. To właśnie uczniowie powinni dociekać, odkrywać, zastanawiać się, jak coś działa, szukać podobieństw i na ich podstawie formułować definicje. Uczenie się przez działanie, uczenie przez dociekanie i stawianie pytań, formułowanie wniosków z obserwacji - to metody, które aktywizują nie tylko ucznia perfekcyjnie władającego językiem polskim, ale również tego, który, mimo problemów z językiem edukacji szkolnej, jest w stanie zrozumieć zagadnienie przy pomocy analizy zjawiska lub materiału.

Niestety, w praktyce bardzo często proces poznania i przekazywania wiedzy rozpoczyna się od podania przez nauczyciela tematu oraz definicji- napisanej językiem specjalistycznym, jednakowej dla wszystkich, często trudnej do zrozumienia. Uczniowie po jej zapisaniu przechodzą do wykonywania ćwiczeń automatyzujących pojęcie, często nadal niezrozumiałe dla większości. W edukacji IB należy odwrócić tę metodę. Lekcję rozpoczyna się od ćwiczenia, obserwacji zjawiska, eksperymentu. Kolejnym elementem jest wyciągnięcie wniosków i na ich podstawie tworzenie definicji, która nie powinna być jednakowa dla każdego ucznia, a indywidualnie ułożona przez uczniów oraz według ich potrzeb i możliwości językowych. Definiowanie i zapisywanie wniosków staje się podsumowaniem działań edukacyjnych, wieńczy proces uczenia się. Za pomocą tej metody każdy uczeń wychodzi od zrozumienia do zdefiniowania, dzięki czemu zapamiętuje materiał na dłużej.

Opisywana przeze mnie metoda stanowi wyzwanie również dla nauczyciela. Według międzynarodowego systemu nauczania pedagog staje na pozycji mentora, lidera, a nawet prowokatora, który doprowadzi ucznia do zrozumienia tematu, zapewniając mu materiały i narzędzia. Taki lider kieruje procesem uczenia się i stopniowego dochodzenia do wiedzy. Prowokuje uczniów do zadawania pytań 
i dociekania odpowiedzi. Dzięki temu uczeń sam odkrywa tajniki wiedzy, sam dochodzi do tego, na czym polega dane zagadnienie, oraz ostatecznie sam uczy się, a nie jest nauczany. Nauka oparta na zadawaniu pytań i dociekaniu (inquiry-based learning) stawia ucznia w centrum działań edukacyjnych. Nauczyciel powinien rozbudzić wyobraźnię uczniów, przedstawić rzeczywisty problem lub realne zagadnienie w sposób interesujący, czasami tajemniczy. Dzięki temu modelowi uczniowie są aktywni, zaangażowani i włączeni w proces uczenia się, a w konsekwencji, bardziej zmotywowani do nauki. Proces edukacyjny musi być wspomagany pozytywną motywacją oraz odbywać się w atmosferze radości. Zadaniem nauczyciela jest stworzenie środowiska, w którym uczeń nie boi się pytać, bo wie, że jego pomysły będą potraktowane z szacunkiem.

W klasie mieszanej w szczególny sposób należy położyć nacisk na atmosferę $\mathrm{w}$ niej panującą. Uczeń z doświadczeniem migracyjnym, przybywający do polskiej szkoły, który nie jest na zaawansowanym poziomie języka edukacji szkolnej, przejawia większe problemy aklimatyzacyjne niż uczeń rodzimy zmieniający placówkę szkolną. Jak pisze W. Hajduk-Gawron: „osoby poznające język polski potrzebują go do podstawowych celów komunikacyjnych, ale też niejednokrotnie do doświadczenia wspólnoty z rodzimymi użytkownikami polszczyzny" (Hajduk-Gawron 2019, s. 251). Dlatego też tak ważne jest, by zadbać zarówno o rozwój językowy, jak i społeczny uczniów z doświadczeniem migracyjnym. Zadanie to realizować powinien nie tylko nauczyciel-wychowawca, ale każdy pedagog w polskiej szkole.

Elementy edukacji IB z powodzeniem mogą być wykorzystywane na lekcjach w klasie mieszanej. Podstawowe zagadnienia tego systemu: nauczanie przez dociekanie (inquiry-based learning) i nauczanie przez działanie (learning by doing), a także nauka $\mathrm{w}$ atmosferze radości, przyniosą korzyści edukacyjne zarówno dla uczniów rodzimych, jak i uczniów z doświadczeniem migracyjnym.

\subsection{PROPOZYCJE DYDAKTYCZNE WPROWADZAJACCE ELEMENTY EDUKACJI IB NA LEKCJACH JĘZYKA POLSKIEGO W KLASACH WIELOKULTUROWYCH}

Jako przykład obrazujący powyżej omówione koncepcje przedstawiam lekcję wprowadzającą przydawkę. Metoda, którą opisuję, była testowana w wielu klasach zarówno mieszanych, jak i składających się jedynie z uczniów rodzimych. Zajęcia powinno się oprzeć na trzech filarach, z których pierwszy dotyczy sytuacji realnej. Nauczyciel polonista prosi uczniów o opisanie różnych elementów w klasie szkolnej. Uczniowie mają za zadanie zwrócenie uwagi na kolor, rozmiar, materiał, z którego został dany element wykonany, liczbę elementów oraz, jeśli to możliwe, określić właściciela przedmiotu. Wszyscy uczniowie proponują słowa opisujące dany 
przedmiot, dzięki czemu każdy może skorzystać z zasobu znanych mu słów, a leksemy wymieniane przez uczniów mają różny stopień trudności. Wybrane z propozycji uczniów słowa nauczyciel zapisuje na tablicy. Kolejną czynnością jest stworzenie pytań do widniejących na tablicy leksemów. Uczniowie zastanawiają się, w jakie grupy można połączyć dane słowa. Wspólne, grupowe rozważania szybko doprowadzą do konkluzji: jedna grupa dotyczy wyglądu, druga właścicieli przedmiotu, trzecia liczby, czwarta kolejności, piąta materiału, sposobu wykonania. Po utworzeniu grup nauczyciel prosi o zastanowienie się nad pytaniami, które można byłoby zadać, tak by odpowiedzią były leksemy wymienione przez uczniów. Dociekliwi uczniowie zaczynają rozumieć, że pierwsze zadanie nie polegało jedynie na opisie danego przedmiotu, a również na zagadnieniu gramatycznym, szukają więc pytań liczebnika, przymiotnika (części mowy, jakimi wyrażona jest przydawka, powinny być wprowadzone na kolejnej jednostce lekcyjnej). Pojawiają się odpowiedzi: „Jaka? Czyja? Czego? Która? Ile? Z czego?” Tym sposobem uczniowie dochodzą do tego, na jakie pytania odpowiada przydawka, mimo że nie poznali jeszcze terminu ani definicji. Kolejna część lekcji poświęcona jest rozpoznaniu, nazwaniu funkcji przydawki. Nauczyciel zapisuje kilka wybranych rzeczowników na tablicy i prosi, by uczniowie dopisali ich określenia, odpowiadając na pytania, które wymienili. Po sprawdzeniu poprawności wykonania ćwiczenia polonista pyta o cel wykonanego ćwiczenia. Bardzo często pojawia się w tym miejscu odpowiedz „Opisywaliśmy przedmiot”. Należy wtedy skierować myślenie klasy na kontekst gramatyczny, pytając, jaka część mowy nazywa przedmioty. Dzięki temu uczniowie zauważają funkcję przydawki - określanie rzeczownika. W tym momencie uczniowie powinni zapoznać się ze standardowymi ćwiczeniami polegającymi na wyszukiwaniu przydawki w tekście, dopisywaniu przydawek w luki. Jednostkę lekcyjną można zamknąć, podając temat: „Określamy rzeczowniki”. Druga lekcja koncentrująca się wokół przydawki polega na odszukaniu części mowy, którymi jest ona wyrażona. Uczniowie mogą szukać znanych im części mowy w ćwiczeniach wykonanych na poprzedniej lekcji. Wyszukują rzeczowniki, przymiotniki, liczebniki, wyrażenia przyimkowe, zaimki. Następnie rozpoczyna się utrwalanie pojęcia w zadaniach, np. proszę opisać rzeczownik ,plecak” za pomoca różnych części mowy. Po części automatyzującej zagadnienie należy wprowadzić termin przydawka i poprosić o jego zdefiniowanie na podstawie zagadnień poruszanych na dwóch lekcjach. Nauczyciel może naprowadzać uczniów, pytając, do czego służy przydawka, czy jest to część mowy czy część zdania, za pomocą czego jest wyrażona. Definicja zostaje zapisana indywidualnie przez każdego ucznia, nauczyciel sprawdza jedynie poprawność zapisu. Ostatnie zadanie to podsumowanie pracy, refleksja uczniów, odpowiedź na pytania: „,zego się dziś nauczyłem?”, „co muszę poćwiczyć?”, „,o mnie zaciekawiło?”, „czego się dowiedziałem?”. Powyższy przykład lekcji wprowadzającej przydawkę pokazuje, że nie trzeba perfekcyjnie i płynnie mówić w języku polskim, by zrozumieć zagadnienia poruszane na lekcji 
języka polskiego. Zaproponowany schemat nauczania angażuje uczniów do pracy, absorbuje ich uwagę i wymaga ich aktywności. Podczas tak skonstruowanej lekcji uczniowie nie są bierni i przejmują odpowiedzialność za wykonanie zadań.

Za pomocą tej metody można wprowadzać nie tylko treści gramatyczne czy językowe. Z powodzeniem można wykorzystać ją chociażby w nauce pisania. Omawiając lekturę dodatkową Harry Potter i Kamień Filozoficzny, można nawiązać do sztuki pisania listu. Każdy uczeń Szkoły Magii i Czarodziejstwa Hogward dostawał oficjalny list od dyrektora informujący o przyjęciu do placówki. Na lekcji poprzedzającej rozważania na temat tej lektury uczniowie również mogą otrzymać podobnie wyglądający list. Adresowany jest on indywidualnie do każdego ucznia, jednak jego treść pozostaje niezmieniona. Za pomocą takiej formy rozpoczęcia zajęć nauczyciel spełnia cel edukacji IB - zaciekawienie materiałem. Na jednej z kolejnych lekcji dotyczących lektury następuje omówienie listów. Nauczyciel wyświetla lub rozdaje kolejny list oficjalny z prośbą o zgodę na zorganizowanie wycieczki szkolnej do Hogsmeade, czarodziejskiej wioski, o której mowa w serii o Harrym Potterze. Uczniowie porównują oba listy pod względem formy i treści. Na plakacie w grupach czteroosobowych dzieci rysują schemat listu, jednak nie uzupełniają go słowami (ważne jest tutaj rozrysowanie kolejnych elementów w odpowiednich miejscach). Następnym punktem lekcji jest nazwanie rozrysowanych elementów: miejsce i data, dane nadawcy, dane adresata, zwrot grzecznościowy, treść, zwrot kończący list oraz podpis. Kończąc tę część lekcji, nauczyciel prosi o stworzenie wspólnie mapy myśli, w której centrum jest słowo list. Zazwyczaj padają odpowiedzi: prywatny (znany uczniom od klasy czwartej), elektroniczny, priorytetowy, zwykły. Uczniowie wspólnie próbują nazwać list, który otrzymali od nauczyciela. Polonista, pytając o charakter i prosząc o porównanie z listem do kolegi, naprowadza na słowo oficjalny. Następnie klasa zastanawia się wspólnie, po co pisać listy oficjalne. W tym celu porównujemy listy, które uczniowie uprzednio otrzymali. Kolejnym zadaniem jest uzupełnienie przygotowanych wcześniej przez uczniów szablonów tekstem. Grupy zbierają słownictwo dotyczące poszczególnych elementów wypisanych na plakacie, pamiętając, że zwroty muszą mieć charakter oficjalny. Tę część pracy wieńczy wspólne uzupełnienie szablonu listu. Uczniowie dostają kilka tematów związanych z lekturą, które mogą poruszyć w liście, np.:

1. Proszę napisać list oficjalny do Dyrektora Szkoły Magii i Czarodziejstwa z prośbą o udzielenie zgody na otwarcie Działu Ksiag Zakazanych w szkolnej bibliotece.

2. Proszę napisać list oficjalny do nauczycieli Hogwartu z prośbą o utworzenie zajęć polegających na konstruowaniu magicznych zabawek.

3. Proszę napisać list oficjalny do Ministra Magii z prośbą o możliwość stosowania zaklęć w świecie mugoli (zwykłych ludzi).

Warto zauważyć, że w proponowanych powyżej rozwiązaniach rola nauczyciela ogranicza się do prowokowania uczniów, zadawania pytań i kontrolowania 
postępów. Nie budzi wątpliwości, że jest to metoda oparta na nauczaniu przez działanie i dociekanie. Edukatorzy IB podkreślają, że metody te są efektywniejsze niż tradycyjne metody podawcze. W kontekście niniejszego artykułu należy jednak zastanowić się, dlaczego mogą one funkcjonować na lekcjach w klasie mieszanej - co zyskuje nauczyciel, który wykorzystuje je do pracy w klasie z dziećmi rodzimymi i uczniami z doświadczeniem migracyjnym?

W. Hajduk-Gawron wskazuje na istotną rolę procesu akomodacyjnego i adaptacyjnego dzieci cudzoziemskich w polskiej szkole. Jak pisze badaczka, ,pełna adaptacja międzykulturowa zakłada zdolność człowieka do zredukowania niepewności i niepokoju oraz łączy się bezpośrednio z umiejętnością efektywnej komunikacji między przedstawicielami różnych kultur" (Hajduk-Gawron 2019, s. 10). Autorka zauważa, że dzieci cudzoziemskie, szczególnie na początku pobytu w nowej szkole i nowym kraju, mogą czuć się „obce” i ,inne”. Dlatego też istotną rolę odgrywa nauczyciel, który powinien doprowadzić do inkluzji, rozumianej jako włączenie do nowej, obcej społeczności. W powyżej przedstawionych przykładach działań edukacyjnych dominuje współdziałanie wszystkich członków grupy społecznej, jaką jest klasa szkolna. Uczniowie pracują zazwyczaj w grupach czteroosobowych, wymieniają się pomysłami, dyskutują, dochodzą do wspólnego rozwiązania przedstawionego przed nimi problemu. Wspólna praca wzmacnia umiejętności społeczne - dziecko uczy się zachowywania w określonej kulturowo grupie społecznej, ma też przestrzeń do spotkania towarzyskiego na lekcji (służą temu stoliki ustawione w tzw. „wyspy”). Uczniowie siedzą obok i naprzeciwko siebie, mają więc zapewniony kontakt wzrokowy, a praca jednej osoby motywuje pozostałych do działania. Dodatkowo dzięki temu podejściu kształtowane są umiejętności komunikacyjne, a także umiejętność myślenia i wyrażanie siebie poprzez prezentowanie własnych idei i pomysłów. Będąc w grupie rówieśniczej, dziecko z doświadczeniem migracyjnym czuje się bezpieczniej, integracja z innymi uczniami nie jest tak wymagająca, jak nawiązanie kontaktu z nauczycielem, osobą starszą, przed którą uczniowie czują respekt, która często posługuje się bardziej skomplikowanym językiem. Obserwacje klas mieszanych, z którymi pracowałam, pokazały, że dzieci z doświadczeniem migracyjnym chętniej pracują, są bardziej aktywne i częściej zabierają głos na forum klasy, gdy swoje wypowiedzi mogą poprzedzić konsultacją z grupą rówieśniczą.

\section{PODSUMOWANIE}

Polska jest krajem, w którym z roku na rok środowisko edukacyjne staje się coraz bardziej zróżnicowane kulturowo, co stawia przed systemem edukacji wiele wyzwań na gruncie nauczania języka pierwszego w grupie mieszanej i języka 
drugiego. Jak zauważają badacze przywołani w moich rozważaniach, konieczne jest tworzenie warsztatu pracy nauczyciela glottodydaktyka. Jedynie specjalista, dobrze przygotowany pedagog, posiadający sprawdzoną i profesjonalną bazę materiałów może $\mathrm{w}$ wymierny sposób pomóc uczniom $\mathrm{z}$ doświadczeniem migracyjnym. Nadal brakuje również rozwiązań systemowych związanych ze statusem zawodowym nauczycieli glottodydaktyków.

W niniejszym artykule przedmiotem refleksji były inspiracje płynące z edukacji IB dla kształcenia polonistycznego. Jednak by doprowadzić do pełnej inkluzji dzieci cudzoziemskich oraz tych z doświadczeniem migracji w realiach szkolnych, również nauczyciele pozostałych przedmiotów szkolnych powinni czerpać z metody nauczania przez działanie i nauczania przez dociekanie. Nie można zapominać o tym, że potrzeby kulturowe, społeczne i językowe uczniów z doświadczeniem migracyjnym nie kończą się po dwunastu miesiącach pobytu w polskiej szkole. Korzystanie z opisanych przeze mnie propozycji edukacyjnych umożliwi uczniom rodzimym i cudzoziemskim aktywny udział w lekcji oraz przyczyni się do poprawienia poczucia bezpieczeństwa i akceptacji w społeczności szkolnej w kolejnych latach nauki.

\section{BIBLIOGRAFIA}

Bernacka-Langier A. i in., 2010, Ku wielokulturowej szkole w Polsce, Warszawa.

Bruner, J.S., 1960, The Process of Education, Cambridge.

Bruner J.S., Haste H., 1987, Making sense. The child's construction of the world, New York.

Dewey J., 1972, Demokracja i wychowanie, Wrocław.

ESOKJ - Europejski system opisu ksztatcenia językowego: uczenie się, nauczanie, ocenianie, 2003, Warszawa.

Fihel, A., 2014, Koszt edukacji cudzoziemskich dzieci „Biuletyn Migracyjny”, nr 49, http://biuletynmigracyjny.uw.edu.pl/49-pazdziernik-2014/koszt-edukacji-cudzoziemskich-dzieci -a [29.05.2020].

Gębal P.E., 2010, Dydaktyka kultury polskiej w ksztatceniu językowym cudzoziemców, Kraków.

Gębal P.E., 2018, Podstawy dydaktyki języka polskiego jako drugiego. Podejście integracyjno-inkluzyjne, Kraków.

Hajduk-Gawron W., 2019, Strategie akulturacyjne a glottodydaktyka, w: K. Frukacz (red.), Literatura polska w świecie. Recepcja i adaptacja-mecenaty i migracje. Prace ofiarowane profesorowi R. Cudakowi, Katowice.

https://www.gov.pl/web/edukacja/nauka-dzieci-przybywajacych-z-zagranicy-w-polskim-systemie -edukacji [29.05.2020].

https://www.ibo.org/about-the-ib/mission/ [29.05.2020].

Janowska I., 2011, Podejście zadaniowe do nauczania i uczenia się języków obcych, Kraków.

Krasuska-Betiuk M., 2015, Interakcje w klasie szkolnej z perspektywy społecznych reprezentacji i oczekiwań interpersonalnych, „Studia z Teorii Wychowania”, t. VI, nr 3, s. 49-77.

Lipińska E., Seretny A., 2012, „Język odziedziczony” w szkołach polonijnych, „Głos Nauczyciela”, R. XXVII, nr 1, s. 65-68.

Lipińska E., Seretny A., 2016, Język odziedziczony - polszczyzna pokoleń polonijnych, „Poradnik Językowy", nr 10, s. 45-61. 
Lipińska E., Seretny A., 2019, Język odziedziczony a dwujęzyczność - o konieczności badań komparatywnych, „Acta Universitatis Lodziensis. Kształcenie Polonistyczne Cudzoziemców” nr 26, G. Zarzycka, B. Grochala, I. Dembowska-Wosik (red.), s. 287-300. http://dx.doi. org/10.18778/0860-6587.26.20

Majcher-Legawiec U., 2017, Na przerwie i na lekcji-język specjalistyczny w edukacji dzieci i młodzieży z doświadczeniem migracyjnym, „Acta Universitatis Lodziensis. Kształcenie Polonistyczne Cudzoziemców”, nr 24, G. Zarzycka, M. Karasek (red.), s. 243-259, https://doi. org/10.18778/0860-6587.24.18

Miodunka, W., 2010, Polszczyzna jako język drugi. Definicja języka drugiego, w: J.S. Gruchała, H. Kurek (red.), Silva rerum philologicarum: Studia ofiarowane Profesor Marii Strycharskiej -Brzezinie z okazji Jej jubileuszu, Kraków, s. 233-245.

Miodunka W., 2013, O definiowaniu języków ojczystego $i$ obcego oraz o „terminologicznym chaosie” w glottodydaktyce - polemicznie, „LingVaria” VIII, nr 2, s. 275-287. https://doi. org/10.12797/LV.08.2013.16.17

Neill A.S., 1991, Summerill, Katowice.

Pamuła-Behrens M., Szymańska M., 2017, W polskiej szkole. Materiały do pracy z uczniami $z$ doświadczeniem migracji. Przewodnik, http://fundacjareja.eu/wp-content/uploads/2015/11/ PRZEWODNIK-W-POLSKIEJ-SZKOLE.pdf [02.06.2020]

Pfeiffer, W., 2004, Interkulturowa glottopedagogika nowa dyscyplina naukowa? Uwagi do dyskusji, w: C. Badstübner-Kizik, R. Rozalowska-Żądło, A. Uniszewska (red.), Nauczanie i uczenie się języków obcych. Prace ofiarowane Profesor Halinie Stasiak w 70. rocznicę urodzin, Gdańsk, s. 71-84.

Piaget J., 1968, On the Development of Memory and Identity, Barre.

Rozporzadzenie Ministra Edukacji Narodowej z dn. 9 września 2016 roku w sprawie ksztatcenia osób niebędacych obywatelami polskimi oraz osób będacych obywatelami polskimi, które pobieraty nauke w szkołach funkcjonujących w systemach oświaty innych państw, Dz.U. 2016 poz. 1453, http://prawo.sejm.gov.pl/isap.nsf/DocDetails.xsp?id=WDU20160001453, [29.05.2020].

Szybura A., 2016, Nauczanie języka polskiego dzieci imigrantów, migrantów i reemigrantów, „Języki Obce w Szkole”, nr 1, http://jows.pl/artykuly/nauczanie-jezyka-polskiego-dzieci-imigrantow-migrantow-i-reemigrantow, [dostęp 28.05.2020].

Willis J., 1996, A Framework for Task-based Learning, Michigan.

Wygotski, L.S., 1971, Wybrane prace psychologiczne, Warszawa.

\section{Natalia Kuźma}

\section{ELEMENTS OF IB EDUCATION IN POLISH LANGUAGE LESSONS IN MULTICULTURAL CLASSES}

Keywords: IB education, Polish language education, student with migration experience, learning by doing, inquiry-based learning

Abstract. The purpose of this article is to present the issue of teaching Polish in a school class in which at least one student uses Polish as a second language. Researchers dealing with this issue suggest the need to develop materials for teaching Polish as a second language for all educational stages. This article addresses this issue and also provides an introduction to wider research aimed at developing a workshop for a Polish teacher who teaches in a classroom with students with migration experience. The basic question that guides the considerations here relates to the effectiveness of teaching: how to teach and what educational activities to use to engage in the teaching process for both of the groups of students: for whom Polish is the first language and for whom it is a second language? The text presents teaching methods used in international education and suggestions for their adaptation in Polish language lessons in multicultural classes. 